\title{
En kartlegging av forekomsten av forskjellige rusmidler blant norske motorvognførere pågrepet av politiet, med mistanke om påvirket kjøring
}

\author{
Kari-Mette Beylich, Asbjørg S. Christophersen, Svetlana Skurtveit, \\ Anders Bjørneboe og Jørg Mørland
}

Statens rettstoksikologiske institutt, Postboks 9934 Ila, 0132 Oslo

Korrespondanse til Kari-Mette Beylich

\begin{abstract}
SAMMENDRAG
Sjåfører som mistenkes for påvirket kjøring blir i første omgang vurdert av politiet med henblikk på om det kun skal rekvireres alkoholanalyse eller om det også skal tas prøve med hensyn på andre rusmidler (narkotika, medikamenter med ruspotensial) ved Statens rettstoksikologiske institutt (SRI). Rutinemessig vil SRI undersøke det politiet rekvirerer, men prøvene lagres inntil to år etter at de er analysert. Ved supplerende analyse i ettertid kan man således få et mer fullstendig bilde av hva mistenkte, påvirkede bilførere hadde i kroppen da de avga prøve. I den foreliggende undersøkelsen ble 1197 prøver fra februar og september 1993 analysert på et bredt spekter av andre rusmidler foruten alkohol, uavhengig av hva politiets mistanke hadde vært. Vi fant da at alkohol alene var til stede i $55 \%$ av prøvene, andre rusmidler alene i $16 \%$, både alkohol og andre rusmidler i $14 \%$, mens verken alkohol eller andre rusmidler ble påvist i $15 \%$ av prøvene. Politiets mistanke med hensyn til alkoholpåvirkning ble bekreftet av analyseresultatene i $71 \%$ av tilfellene, og mistanke om forekomst av andre rusmidler i $58 \%$ av tilfellene. Tidligere studier og denne undersøkelsen viste at bilførere som mistenkes for påvirket kjøring synes å representere en gruppe med storbruk av alkohol og misbruk av andre stoff.
\end{abstract}

Beylich K-M, Christophersen AS, Skurtveit S, Bjørneboe A, Mørland J. Frequency of different drugs in samples from Norwegian drivers suspected for impaired driving. Nor J Epidemiol 1996; 6 (1): xx-Xx.

\section{ENGLISH SUMMARY}

Drivers apprehended under the suspicion of drunken or drugged driving are primarily evaluated by the police with regard to whether alcohol or drugs should be looked for in the blood samples taken shortly after apprehension. Until March 1996 all blood samples were sent to the National Institute of Forensic Toxicology (NIFT), for analysis. NIFT routinely perform only those analyses requested, but the samples are stored for up to two years after analysis. By later additional analyses of this material one could obtain a more complete picture of which drugs were present in the drivers at the time of blood sampling. In the present study, 1197 samples collected during February and September 1993, were analyzed for a broad spectrum of drugs in addition to alcohol, regardless of what the suspicion by the police had been. We found that alcohol only was present in 55 per cent of the samples, drugs only in 16 per cent, both alcohol and drugs in 14 per cent, while neither alcohol nor drugs were present in 15 per cent of the samples. Drugs were detected more frequently in samples which did not contain alcohol (in 64 per cent of the samples), while the frequency of detection was from 18 to 25 per cent in samples where alcohol was present. In the majority of the samples with drugs present, alcohol and/or another drug was present too. The suspicion by the police with respect to alcohol influence was confirmed in 71 per cent of cases, and the suspicion of the presence of other drugs was verified in 58 per cent of cases. Earlier studies and the present demonstrated that drivers suspected for drunken/ drugged driving represent a group with heavy drinking and drug abuse.

\section{BAKGRUNN}

I følge den norske veitrafikkloven er det forbudt å føre eller forsøke å føre motorvogn under påvirkning av alkohol eller andre berusende eller bedøvende midler. De fleste sjåfører mistenkt for påvirket kjøring blir stoppet av politiet på grunn av trafikkulykke, uforsvarlig eller uvanlig kjøring, bare ca. 10-15\% blir pågrepet i rutinekontroller. Politiet foretar en primærvurdering av den mistenkte med tanke på om det kun 
skal rekvireres alkoholanalyse eller om det også er ønskelig å ta prøve som skal analyseres på andre rusmidler. Dersom det er ønske om analyse av andre stoffer, tappes det noe mer blod av den mistenkte (utvidet prøve) og vedkommende må også fremstilles for lege som foretar en klinisk undersøkelse. Denne er viktig for en senere vurdering av påvirkningsgrad.

Samtlige prøver som ankommer Statens rettstoksikologiske institutt (SRI) får et registreringsnummer og blir satt opp på egnet analyseprogram. Saker hvor det utelukkende er mistanke om alkoholpåvirkning kodes som A-saker, mens saker der det også er mistanke om andre rusmidler kodes som AT-saker (alkohol- og toksikologiske analyser). For en stor del av sakene til utvidet analyse blir det fra påtalemyndigheten anmodet om en sakkyndig uttalelse i etterkant. Selv om det ikke er grenser for rusmiddelkonsentrasjoner i blod på samme måte som for alkohol, åpner loven for å avsi dommer i saker der det kun påvises andre rusmidler. En undersøkelse foretatt på SRI antyder at det nå blir avsagt over 1000 fellende dommer i løpet av et år på bakgrunn av forekomst av andre rusmidler enn alkohol. SRI lagrer alle blodprøver i minst 2 år slik at det også er mulig for politiet å rekvirere supplerende analyser i ettertid dersom dette skulle være ønskelig.

Fra 1983 til 1993 er antall saker med mistanke om kun alkoholpåvirkning blitt halvert, mens antall saker med mistanke om påvirkning av andre stoffer i tillegg har blitt mer enn tredoblet. I 1983 mottok SRI ca. 10500 prøver med mistanke om kun alkoholpåvirkning og ca. 900 prøver med mistanke om andre rusmidler. I 1993 var antall prøver med mistanke om kun alkoholpåvirkning sunket til ca. 5500, mens antall prøver med mistanke om andre rusmidler var steget til ca. 2900 (1).

SRI undersøker først og fremst det politiet rekvirerer i A- og AT-saker. I de aller fleste A-saker blir det således kun målt alkohol. I AT-sakene undersøkes det rutinemessig på hyppig forekommende rusmidler/ medikamenter (alkohol, amfetamin, benzodiazepiner (beroligende-/sovemidler), cannabisstoffer (THC), opiater (morfin, kodein o.1.), kokain og barbiturater). Det analyseres eventuelt også på andre medikamenter/ rusmidler dersom spesiell mistanke fremkommer i politiets rekvisisjon eller på annen måte av saksdokumentene. Dersom alkoholkonsentrasjonen er over 1,5\% blir det sjelden lett etter andre rusmidler.

Med denne bakgrunn ønsket vi å få et bedre bilde av hva prøvene fra førere som politiet mistenkte for påvirket kjøring, egentlig inneholdt. Vi mente for det første at det var viktig å ha et mer fullstendig bilde av hva mistenkte påvirkede førere hadde i kroppen. For det andre ville en slik undersøkelse gi politiet nyttig tilbakemelding mht. hvor godt primærmistanken stemte overens med analysefunnene. For å få frem disse opplysningene ble en omfattende undersøkelse utført på alle A- og AT-saker som ble mottatt $\mathrm{i}$ et bestemt tidsrom.

\section{MATERIALE OG METODER}

Månedene februar og september 1993 ble valgt ut, og antatt representative. Dette ble bekreftet ved å sammenholde funn fra disse månedene med hele årsmaterialet. Alle prøver som ble sendt til instituttet $\mathrm{i}$ disse to månedene og fylte kriteriene for å inngå $\mathrm{i}$ undersøkelsen, ble analysert på et bredt spekter av rusmidler og medikamenter uavhengig av hva politiets primærmistanke var rettet mot. Kriterier for å inngå i undersøkelsen var at det dreide seg om en prøve fra fører av motorkjøretøy, og at det var innsendt tilstrekkelig materiale (blod) til at vi kunne få utført alle aktuelle analyser på hver eneste prøve. Det var svært få prøver som måtte ekskluderes på dette grunnlag. SRI analyserer alkohol med to ulike metoder, gasskromatografi og enzymatisk analyse. Medikamenter og narkotika screenes oftest ved hjelp av en immunologisk-enzymatisk metode, og prøver som er positive på screening kvantiseres og bekreftes med spesifikke metoder, som oftest gasskromatografi/ massespektrometri (GC/MS). Alkoholresultater og resultater fra rusmiddelanalyser utført i henhold til politiets rekvisisjoner, ble notert etter at prøvene var ferdig analysert og besvart. Deretter ble prøvene kodet på en slik måte at eventuelle tilleggsfunn ikke kunne føres tilbake til og/eller få konsekvenser for den som hadde avgitt prøven. Vi utførte så tilleggsanalyser for samtlige saker. Når disse var utført, var samtlige av februar- og septembersakene fra mistenkte førere av motorkjøretøy analysert på: amfetamin, benzodiazepiner, barbiturater, cannabisstoffer, kokain, opiater, andre smertestillende medikamenter, tricykliske antidepressiva, neuroleptika, antihistaminer og sentralt virkende muskelavslappende medikamenter. Dette innebar en betydelig utvidelse av analyseprogrammet, i første rekke for Asaker og en mer varierende utvidelse for AT-sakene hvor det allerede var utført rutinemessige analyser på en del av stoffene. Med dette analyseprogrammet mener vi å ha fått med det aller meste av illegale stoffer og legemidler som kan ha innflytelse på ferdigheter i trafikken, i tillegg til alkohol. Alle de nevnte illegale stoffene og legemidlene kan gi rus, og vi har videre omtalt dem under fellesbetegnelsen «andre rusmidler».

\section{RESULTATER}

Totalt antall saker inkludert i denne undersøkelsen var 1197. I $62 \%$ av disse var primærmistanken rettet mot alkohol alene, A-saker, og i $38 \%$ mot andre rusmidler, alene eller sammen med alkohol, AT-saker.

Tabell 1 viser fordeling av forekomst av alkohol og andre rusmidler uavhengig av politiets primærmistanke. Det fremgår det at alkoholkonsentrasjonen var over 0.5 promille i $69 \%$ av sakene, $14 \%$ inneholdt et eller flere andre rusmidler i tillegg til alkohol og $16 \%$ inneholdt rusmidler uten samtidig tilstedeværelse av 
Tabell 1. Fordeling av funn av alkohol og andre rusmidler. Alkoholkonsentrasjon under straffegrensen (0.5 promille) er oppført som ikke påvist.

\begin{tabular}{lrrrrc}
\hline & $\mathrm{n}$ & $\boldsymbol{\%}$ & $\begin{array}{c}\text { kvinner } \\
(\%)\end{array}$ & $\begin{array}{c}\text { menn } \\
\mathbf{( \% )}\end{array}$ & $\begin{array}{c}\text { median } \\
\text { alder (år) }\end{array}$ \\
\hline Total & 1197 & 100 & 8 & 92 & 29 \\
Alkohol (påvist) alene & 658 & 55 & 7 & 93 & 28 \\
Andre rusmidler påvist alene & 196 & 16 & 9 & 91 & 29 \\
Både alkohol og andre rusmidler påvist & 166 & 14 & 5 & 95 & 31 \\
Verken alkohol eller andre rusmidler påvist & 177 & 15 & 12 & 88 & 29 \\
\hline
\end{tabular}

alkohol. Fordelingen mellom kvinner og menn er i overensstemmelse med den fordelingen vi normalt ser i våre saker. Median alder varierte lite i de ulike gruppene, dette gjelder også for gjennomsnittsalder (ikke vist).

Tabell 2. Fordeling av sakene i henhold til blodalkoholkonsentrasjonen (BAK) og forekomsten av andre rusmidler ved ulike nivåer av blodalkoholkonsentrasjonen.

\begin{tabular}{lccc}
\hline $\begin{array}{l}\text { BAK } \\
\text { (promille) }\end{array}$ & $\begin{array}{c}\text { Antall } \\
\text { totalt }\end{array}$ & $\begin{array}{c}\text { Antall med } \\
\text { andre rusmidler }\end{array}$ & $\begin{array}{c}\text { Prosentandel med } \\
\text { andre rusmidler }\end{array}$ \\
\hline 0 & 259 & 167 & 64 \\
$0-0.5$ & 114 & 29 & 25 \\
$0.51-1.0$ & 179 & 39 & 22 \\
$1.01-1.55$ & 220 & 50 & 23 \\
$>1.5$ & 425 & 77 & 18 \\
Sum & 1197 & 362 & 30 \\
\hline
\end{tabular}

Tabell 2 viser hvordan sakene er fordelt $i$ henhold til blodalkoholkonsentrasjonene (BAK). Det fremgår av tabellen at forekomsten av andre rusmidler er høyest i prøver som ikke inneholder alkohol. Andre rusmidler påvises i $18-25 \%$ av prøvene som også inneholder alkohol.

Tabell 3 gir en oversikt over positive prøver med funn av andre rusmidler. Vi har vist funn innen fem grupper, amfetamin, benzodiazepiner, cannabisstoffer (THC), opiater og andre stoffer. Gruppen «andre» inkluderer i hovedsak smertestillende medikamenter samt muskelavslappende stoffer. Det ble ikke funnet noen prøver med kokain i denne undersøkelsen. Vi fant heller ikke prøver med funn av antidepressiva eller antihistaminer, men $\mathrm{i}$ en prøve ble det påvist et neuroleptisk medikament (middel mot alvorlig sinnslidelse).

Antall funn i tabell 3 overstiger 362, som var det antall saker hvor det ble påvist andre stoffer. Dette skyldes at mange av prøvene (18\%) inneholdt mer enn et rusmiddel utenom alkohol. $25 \%$ hadde funn av kun ett stoff. I over halvparten av tilfellene hvor benzodiazepiner (som kan brukes legalt), var eneste påviste stoff, var dette i konsentrasjoner som viste bruk av høyere doser enn det som brukes ved behandling.

Tabell 3. Funn av andre rusmidler enn alkohol alene, andre rusmidler sammen med alkohol eller kombinasjoner av ulike typer andre rusmidler i 362 blodprøver positive på andre rusmidler enn alkohol.

\begin{tabular}{lccccc}
\hline & \multicolumn{5}{c}{ Hovedfunn } \\
\cline { 2 - 6 } & Benzodiazepiner & THC & Amfetamin & Opiater & Andre \\
\hline Totalt & 206 & 147 & 81 & 58 & 34 \\
Alene & 19 & 33 & 20 & 8 & 11 \\
Med BAK $>0,5 \%$ o & 103 & 61 & 5 & 21 & 17 \\
Med benzodiazepiner & $23 *$ & 54 & 38 & 19 & 11 \\
Med THC & 54 & - & 39 & 13 & 1 \\
Med amfetamin & 38 & 39 & - & 5 & 1 \\
Med opiater & 19 & 13 & 5 & - & 4 \\
Med andre & 11 & 1 & 1 & 4 & - \\
\hline
\end{tabular}

* Kombinasjoner av ulike benzodiazepiner

Tabell 4. Overensstemmelse mellom analysefunn og politiets mistanke.

\begin{tabular}{lcccc}
\hline & & \multicolumn{3}{c}{ Analysefunn } \\
\cline { 3 - 5 } Politiets mistanke & $\mathrm{n}$ & $\begin{array}{c}\text { Bare alkohol } \\
\text { BAK }>0,5 \% \mathrm{o}\end{array}$ & $\begin{array}{c}\text { Andre } \\
\text { rusmidler }\end{array}$ & $\begin{array}{c}\text { Verken alkohol eller } \\
\text { andre rusmidler }\end{array}$ \\
\hline $\begin{array}{l}\text { Alkohol (A) } \\
\begin{array}{l}\text { Andre rusmidler alene eller } \\
\text { sammen med alkohol (AT) }\end{array}\end{array}$ & 739 & $71,2 \%$ & $13,3 \%$ & $15,6 \%$ \\
\hline
\end{tabular}


Tabell 4 gir en oversikt over hvordan politiets mistanke stemte overens med analysefunnene. I tabellen har vi sett hele landet under ett.

Tabell 4 viser at politiets mistanke i stor utstrekning er i overensstemmelse med analysefunnene. I saker hvor alkohol alene har vært rekvirert er det funnet alkoholkonsentrasjoner over straffegrensen $\mathrm{i}$ ca. $70 \%$ av tilfellene, i $13 \%$ av disse sakene ble imidlertid andre rusmidler oversett. I saker hvor primærmistanken også var rettet mot andre rusmidler (ATsaker), fant man slike i nærmere $60 \%$ av sakene (i 1995, nærmere 65\%), 40\% ble funnet i saker hvor alkoholkonsentrasjonen var under strafferettslig grense.

\section{DISKUSJON}

Undersøkelsen omfatter materiale fra 2 hele kalendermåneder i 1993, og utgjør 15\% av det totale antall prøver analysert ved SRI i 1993. Samtlige av landets fylker er representert og med bakgrunn i den viten vi hadde om sakene ut fra de rutineresultater som allerede forelå, kunne vi vurdere hvor representativ undersøkelsen var. For A-sakene i vårt materiale fant vi samme relative fordeling av målte blodalkoholkonsentrasjoner som i hele årsmaterialet. Med hensyn til AT-sakene var det samme påvisningsfrekvens og samme relative fordeling av andre rusmidler som i hele årsmaterialet. På denne bakgrunn antok vi at funnene vi gjorde i prøver utplukket fra to måneder gav et rimelig bilde av hele årsmaterialet.

Det er få studier tilgjengelig for sammenligning. En studie fra Danmark i 1985 (2), viste at 5.5\% av førere mistenkt for kjøring under påvirkning av alkohol hadde diazepam (virkestoff i valium etc) i blodet. Det er også gjort en undersøkelse i Finland (3) som avdekker en økning i forekomsten av andre rusmidler enn alkohol hos påvirkede førere. Vi har utført noen lignende studier tidligere $(4,5)$ som avdekker utviklingen i Norge. Den undersøkelsen vi presenterer her viser at blant førere mistenkt og pågrepet for påvirket kjøring har flertallet inntatt alkohol. Det ble funnet alkohol alene i blodet i konsentrasjoner over 0.5 promille hos $55 \%$ av de mistenkte. Andre rusmidler enn alkohol, alene eller sammen med alkohol ble funnet hos $30 \%$ av alle mistenkte. I de tilfeller hvor politiet hadde mistanke om andre stoffer i utgangspunktet ble det gjort positive funn i nærmere $60 \%$ av prøvene.

Hos $18 \%$ av alle mistenkte bilførere ble det funnet flere andre rusmidler enn alkohol i prøven fra en og samme person.

Illegale rusmidler (cannabis, amfetamin, illegale opiater) ble funnet hos $16 \%$ av alle mistenkte bilførere, mens legale medikamenter i konsentrasjoner som brukes i behandling ble påvist i kun 1-2\% av alle de mistenkte bilførerne.

Andre rusmidler ble hyppigst funnet i blodprøver som ikke inneholdt alkohol. Står man overfor mistenkte, påvirkede førere som har 0 promille, vil man altså ha en sannsynlighet for å finne andre rusmidler i 2 av 3 tilfelle (se tabell 2).

Andre rusmidler finnes i tillegg til alkohol hos $14 \%$ av alle mistenkte bilførere. Hos bilførere med promille mellom 0.1 og 1.5 vil man i ca. hvert 4 . tilfelle finne andre rusmidler (se tabell 2).

Alle de ovennevnte funn tilsier at en stor andel av de førere som mistenkes for påvirket kjøring også har et rusmiddelmisbruks problem. I flere land er det blitt innført ordninger som setter krav til at personer som er tatt for påvirket kjøring skal dokumentere bedring av sitt rusmiddelproblem før de får igjen førerkortet. Det har vært gjennomført i alt vesentlig for alkoholpåvirkede bilførere, da interessen for påvirkning av andre stoff til nå har vært liten $\mathrm{i}$ andre land. Vår undersøkelse viser at norske bilførere mistenkt for påvirket kjøring synes å representere en gruppe med hyppig storbruk av alkohol (6) og misbruk av andre stoff. Behandling rettet mot rusmiddelproblemet som etter alt å dømme finnes hos flertallet av norske påvirkede bilførere som blir pågrepet av politiet, bør etter vår oppfatning vurderes nærmere.

\section{REFERANSER}

1. Christophersen AS. Trafikkulykker og påvirket kjøring forårsaket av legemiddel- og narkotikabruk. Norsk Farmasøytisk tidsskrift 1993; 3: 4-8.

2. Worm K, Christensen H, Stentoft A. Diazepam in blood from Danish drivers: Occurence as shown by gasliquid chromatographic assay following radireceptor screening. J Forensic Sci Soc 1985; 25: 407-413.

3. Lillsunde P, Korte T, Michelson L, Portman M, Pikkarainen J, Seppälä T. Drugs usage of drivers suspected of driving under the influence of alcohol and/or drugs. A study of one week's samples in 1979 and 1993 in Finland. Forensic Sci Int 1996; 77: 119-129.

4. Christophersen AS, Gjerde H, Bjørneboe A, Sakshaug J, Mørland J. Screening for drug use among Norwegian drivers suspected of driving under influence of alcohol or drugs. Forensic Sci Int 1985; 27: 5-14.

5. Kruse S, Christophersen AS. Kjøring under påvirkning av alkohol, legemidler og narkotika. Tidsskr Nor Lageforen 1994; 114: 429-431.

6. Gjerde H. Alcohol consumption levels among drunken drivers. Doktoravhandling, Universitetet i Oslo, 1988 (ISBN 82-90730-01-2). 